Яковлева Т. А., Иванова Е. С.

T. A. Yakovleva, E. S. Ivanova ПРОБЛЕМЫ СОЗДАНИЯ МЕХАНИЗМА АНТИКРИЗИСНОГО УПРАВЛЕНИЯ
В РОССИЙСКОЙ ЭКОНОМИКЕ

\title{
ISSUES OF CREATING A CRISIS MANAGEMENT MECHANISM IN THE RUSSIAN ECONOMY
}

Яковлева Татьяна Анатольевна - кандидат экономических наук, доцент кафедры экономики, финансов и бухгалтерского учёта Комсомольского-на-Амуре государственного университета (Россия, Комсомольскна-Амуре); 681013, Хабаровский край, г. Комсомольск-на-Амуре, пр. Ленина, 27. E-mail: efbu@knastu.ru.

Ms. Tatiana A. Yakovleva - PhD in Economics, Associate Professor, Department of Economics, Finance and Accounting, Komsomolsk-on-Amur State University (Russia, Komsomolsk-on-Amur); 681013, Khabarovsk territory, Komsomolsk-on-Amur, 27 Lenin str. E-mail: efbu@knastu.ru.

Иванова Екатерина Сергеевна - магистрант кафедры экономики, финансов и бухгалтерского учёта Комсомольского-на-Амуре государственного университета (Россия, Комсомольск-на-Амуре); 681013, Хабаровский край, г. Комсомольск-на-Амуре, пр. Ленина, 27. E-mail: ivanova_katerine@mail.ru.

Ms. Ekaterina S. Ivanova - Master's degree student, Economics, Finance and Accounting Department, Komsomolsk-on-Amur State University (Russia, Komsomolsk-on-Amur); 681013, Khabarovsk territory, Komsomolskon-Amur, 27 Lenin str. E-mail: ivanova_katerine@mail.ru.

Аннотация. В статье представлены выявленные обстоятельства актуальности и необходимости антикризисного управления в России; сформирована сравнительная матрица основных видов антикризисного управления. Определены основные проблемы создания механизма антикризисного управления организации, с которыми сталкиваются российские предприятия.

Summary. In article the circumstances of the relevance and necessity of crisis management in Russia are revealed. A comparative matrix of the main types of crisis management in Russia has been formed. The main problems of creating a mechanism of crisis management of an organization that Russian enterprises face are identified.

Ключевые слова: кризис, антикризисное управление, экономическая стабильность, механизм антикризисного управления, проблематика создания антикризисного управления.

Key words: crisis, crisis management, economic stability, mechanism of crisis management, the problems of creating crisis management.

УДК 338.2

В условиях современной мировой экономической нестабильности российским предприятиям приходится буквально «выживать» на рынке, преодолевая последствия экономического кризиса. Основными последствиями кризиса, повлиявшими на экономическое развитие хозяйствующих субъектов, являются:

- внутренние проблемы функционирования предприятий в сфере организации производства;

- вынужденные меры государства по координации своей экономической политики, основанной на активизации процессов приватизации;

- поиск новых методик и подходов в управлении предприятием с целью усовершенствования механизма управления и недопущения усугубления кризисных ситуаций.

Таким образом, создание комплексного механизма финансового управления предприятием целесообразно как в кризисный период, так и задолго до его наступления.

Управление финансовой системой предприятия всегда должно быть антикризисным. Это объясняется тем, что опасность кризиса может появиться в любой момент, даже когда он не наблюдается. Всегда существует риск цикличности финансовой системы, а соотношение 
Яковлева Т. А., Иванова Е. С.

ПРОБЛЕМЫ СОЗДАНИЯ МЕХАНИЗМА АНТИКРИЗИСНОГО УПРАВЛЕНИЯ В РОССИЙСКОЙ ЭКОНОМИКЕ

управляемых и неуправляемых процессов меняется: время от времени меняются потребности человека и его интересы.

По мнению отечественных авторов, под антикризисным управлением понимается управление, способное предвидеть опасность кризиса, анализировать симптомы и меры по снижению негативных кризисных последствий, а также использование его факторов для последующего развития. Важнейшую роль здесь играет человеческий фактор. Именно действия человека позволяют найти пути выхода организации из кризиса, используя при этом накопленный годами опыт преодоления кризисных ситуаций.

Основные проблемы создания механизма антикризисного управления представлены в совокупности четырьмя группами (см. рис. 1).

Первая группа рассматривает проблемы распознавания предкризисных ситуаций. Так, наиболее важным при формировании механизма антикризисного управления является своевременно выявленный процесс наступления кризиса. Важно распознать первые признаки и понять характер кризисной ситуации. При этом механизм антикризисного управления нужно построить таким образом, чтобы не навредить организации. Это связано с тем, что не все кризисы можно предотвратить, некоторые из них нужно пережить.

Вторая группа представляет собой методологические проблемы создания механизма антикризисного управления. Здесь рассматриваются такие проблемы, как проблемы социальнопсихологического характера, проблемы организационного и правового содержания и др.

Третья группа отражает проблемы поиска информации, проблемы прогнозирования кризисных ситуаций, а также проблемы разработки управленческих решений.

\begin{tabular}{|c|c|c|}
\hline $\begin{array}{l}\text { Проблемы распознавания } \\
\text { предхризисных ситуаций }\end{array}$ & & \multirow{2}{*}{$\begin{array}{c}\begin{array}{c}\text { Методологические проблемы } \\
\text { антикризисного управления }\end{array} \\
\begin{array}{c}\text { Финансово-экономические } \\
\text { проблемы антикризисного } \\
\text { управления }\end{array}\end{array}$} \\
\hline $\begin{array}{l}\text { Проблемы предотвращения } \\
\text { кризиса }\end{array}$ & + & \\
\hline $\begin{array}{l}\text { Проблемы жизнедеятельности } \\
\text { организачии в кризисном } \\
\text { состоянии }\end{array}$ & & $\begin{array}{c}\text { Правовые проблемы } \\
\text { антикризисного управления }\end{array}$ \\
\hline $\begin{array}{l}\text { Проблемы выхода } \\
\text { из хризиса }\end{array}$ & & $\begin{array}{c}\text { Проблемы организачии } \\
\text { антикризисного управления }\end{array}$ \\
\hline $\begin{array}{l}\text { Пробпемы ликвидации } \\
\text { последствий кризиса }\end{array}$ & 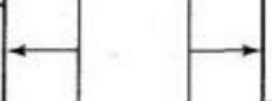 & $\begin{array}{l}\text { Социально-психологические } \\
\text { проблемы антихризисного } \\
\text { управления }\end{array}$ \\
\hline- & & i \\
\hline \multicolumn{3}{|c|}{$\begin{array}{c}\text { Антикризисное управление: } \\
\text { методологияиорганизациярешенияпроблемвусловияхкризисного } \\
\text { фуункционированияорганизации } \\
\end{array}$} \\
\hline Поиск информации & \multirow{5}{*}{. } & $\begin{array}{l}\text { Конфликтопогические } \\
\text { проблемы управления }\end{array}$ \\
\hline $\begin{array}{c}\text { Проблемы прогнозирования } \\
\text { кризисов }\end{array}$ & & $\begin{array}{c}\text { Маркетинг: nоведение } \\
\text { в условиях неопределенности }\end{array}$ \\
\hline $\begin{array}{l}\text { Разрабопка управленчесхих } \\
\text { решений в условиях рисха }\end{array}$ & & $\begin{array}{l}\text { Внешнее управление } \\
\text { и проблемы санации }\end{array}$ \\
\hline $\begin{array}{l}\text { Анализ и оценка } \\
\text { хризисных ситуаций }\end{array}$ & & $\begin{array}{l}\text { Селекция персонала } \\
\text { в условиях кризиса: } \\
\text { оценка и мотивирование }\end{array}$ \\
\hline $\begin{array}{c}\text { Инновационные стратегии } \\
\text { кризисного поведения }\end{array}$ & & $\begin{array}{l}\text { Инвестиционное } \\
\text { проектироеание. }\end{array}$ \\
\hline
\end{tabular}

Рис. 1. Проблематика создания механизма антикризисного управления [2]

Конфликтологию и селекцию персонала, которые всегда сопровождают кризисные ситуации, представляет четвёртая группа проблем антикризисного управления. Здесь тоже выделены 
проблемы инвестирования антикризисных мер, а также проблемы банкротства и санации организации. В настоящее время в связи с турбулентностью мировой экономической системы, а также в связи с введёнными Западом санкциями в отношении России в экономике страны появилась острая необходимость в обеспечении поступательного развития и устойчивости к неблагоприятным факторам развития хозяйствующих субъектов, прежде всего предприятий реального сектора экономики. В России с 2009 по 2017 годы коэффициент официальной ликвидации вырос более чем в четыре раза - с 20,9 до 87,3 единиц на 1 тыс. организаций (см. рис. 2).

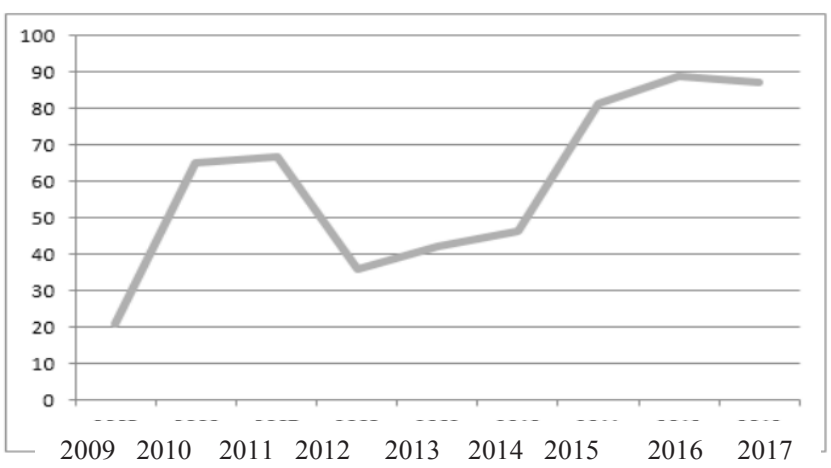

Рис. 2. Количество официально ликвидированных организаций на 1 тыс. предприятий

Таким образом, внедрение антикризисного управления является актуальным на сегодняшний день и должен быть создан комплексный механизм устойчивого развития предприятий, который будет решать комплекс взаимосвязанных задач (см. рис. 3).

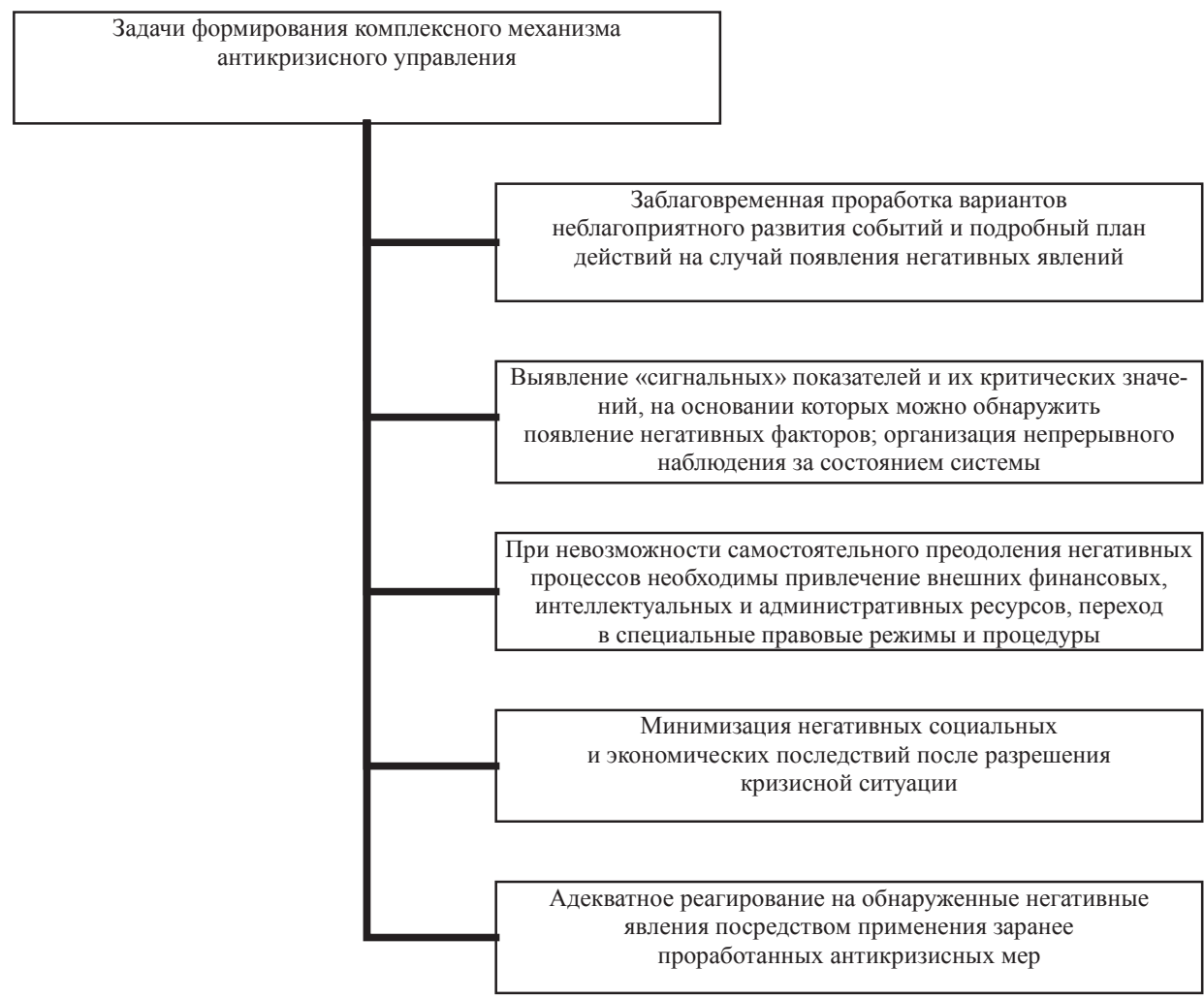

Рис. 3. Совокупность основных задач создания механизма антикризисного управления в современной экономике

В табл. 1 представлено сравнение основных видов антикризисного управления в современной концепции Российской Федерации. 
Основные виды и особенности антикризисного управления в России

\begin{tabular}{|c|c|c|c|}
\hline $\begin{array}{c}\text { Вид антикризисного } \\
\text { управления }\end{array}$ & Цель & Особенности & $\begin{array}{c}\text { Реализуемый принцип } \\
\text { антикризисного управления }\end{array}$ \\
\hline Антиципативное & $\begin{array}{l}\text { Наилучшим образом } \\
\text { подготовиться к кризису }\end{array}$ & $\begin{array}{l}\text { Требует затрат ресурсов, } \\
\text { когда реальной угрозы } \\
\text { ещё нет }\end{array}$ & $\begin{array}{l}\text { Предварительная разра- } \\
\text { ботка моделей реагирова- } \\
\text { ния и поведения в случае } \\
\text { кризиса }\end{array}$ \\
\hline Превентивное & $\begin{array}{l}\text { Купировать кризисные } \\
\text { явления прежде, чем } \\
\text { они разовьются }\end{array}$ & $\begin{array}{l}\text { Объективно не может } \\
\text { предотвратить все кризи- } \\
\text { сы, но снижает их опас- } \\
\text { ные последствия }\end{array}$ & $\begin{array}{l}\text { Чем раньше обнаружить } \\
\text { кризис, тем легче с ним } \\
\text { справиться }\end{array}$ \\
\hline Реактивное & $\begin{array}{l}\text { Сохранение деятельно- } \\
\text { сти во время кризиса } \\
\text { и поиск способа вер- } \\
\text { нуться в стабильное со- } \\
\text { стояние }\end{array}$ & $\begin{array}{l}\text { Не связано с необходимо- } \\
\text { стью защищать интересы } \\
\text { собственников объекта } \\
\text { управления }\end{array}$ & $\begin{array}{l}\text { Неважно, кому принадле- } \\
\text { жит объект управления, } \\
\text { главное, чтобы он мог эф- } \\
\text { фективно функциониро- } \\
\text { вать }\end{array}$ \\
\hline Реабилитационное & $\begin{array}{l}\text { Усилить сопротивляе- } \\
\text { мость объекта управле- } \\
\text { ния после завершения } \\
\text { кризиса, снизить нега- } \\
\text { тивные социальные } \\
\text { последствия }\end{array}$ & $\begin{array}{l}\text { Нет разработанной теории } \\
\text { и системно применяемой } \\
\text { практики }\end{array}$ & $\begin{array}{l}\text { Обновляющий потенциал } \\
\text { кризиса следует использо- } \\
\text { вать для развития }\end{array}$ \\
\hline
\end{tabular}

Подводя итоги, можно выделить следующие проблемы создания механизма антикризисного управления в российской экономике:

- системы антикризисного управления, созданные на основе зарубежного опыта, были предназначены для работы в стабильных условиях экономики, следовательно, в условиях снижения деловой активности на мировых рынках эти системы оказались непригодными;

- меры, предпринимаемые государством, как правило, имеют запоздалый характер и не направлены на ликвидацию причин кризиса;

- системы управления делают упор на устранении нарушений в области финансовокредитной сферы, а не на создании новой инновационной платформы предприятия;

- наблюдается отставание в области правового регулирования кризиса; правовой механизм ориентирован на разрешение выхода из кризиса посредством банкротства;

- проблема распознавания сущности кризиса, что впоследствии приводит к ошибочной разработке путей преодоления кризиса посредством механизма антикризисного управления.

Таким образом, механизм антикризисного управления - это эффективный инструмент, который позволяет проводить комплексные процедуры оздоровления организации, внедряя при этом новые системы управления финансовой политики фирмы, что позволяет сохранить как предприятие, так и существующую клиентскую базу, рабочие места.

\section{ЛИТЕРАТУРА}

1. Галимов, И. А. Актуальность антикризисного управления для России [Электронный ресурс] / И. А. Галимов, Л. Н. Ардеева // Молодой учёный. - 2014. - № 9. - С. 261-263. - Режим доступа: https://moluch.ru/archive/68/11685/ (дата обращения: 09.11.2018).

2. Коротков, Э. М. Антикризисное управление / Э. М. Коротков. - М.: ИНФРА-М, 2016. - 432 с.

3. Проблемы развития антикризисного управления в современной России [Электронный ресурс]. - Режим доступа: http://uecs.ru/index.php?option=com_flexicontent\&view $=\quad$ items\&id $=2930$ (дата обращения: 09.11.2018).

4. Влияние антикризисного управления предприятия на экономику РФ в современных условиях [Электронный pecypc]. - Режим доступа: http://www.fundamental-research.ru/ru/article/view?id=41829 (дата обращения: 09.11.2018). 